\title{
Ethnologies
}

\section{Men at Play: A Working Understanding of Professional Hockey. By Michael A. Robidoux. (Montreal and Kingston: \\ McGill-Queen's University Press, 2001, 222.p. ISBN 0-7735-2169-0 \\ cloth; ISBN 0-7735-2220-4 plok).}

\section{Corey Thorne}

Volume 24, numéro 1, 2002

Espace

Space

URI : https://id.erudit.org/iderudit/006543ar

DOI : https://doi.org/10.7202/006543ar

Aller au sommaire du numéro

Éditeur(s)

Association Canadienne d'Ethnologie et de Folklore

ISSN

1481-5974 (imprimé)

1708-0401 (numérique)

Découvrir la revue

Citer ce compte rendu

Thorne, C. (2002). Compte rendu de [Men at Play: A Working Understanding

of Professional Hockey. By Michael A. Robidoux. (Montreal and Kingston:

McGill-Queen's University Press, 2001, 222.p. ISBN 0-7735-2169-0 cloth; ISBN

0-7735-2220-4 pbk).] Ethnologies, 24(1), 297-301.

https://doi.org/10.7202/006543ar d'utilisation que vous pouvez consulter en ligne.

https://apropos.erudit.org/fr/usagers/politique-dutilisation/ 
notices, patriotic displays of one sort and another, and so on. The book itself is a warmhearted example of the range of regional folklore anywhere. Nonetheless, I would not recommend Features as a primary textbook except perhaps within the American Southwest. It is not an especially scholarly book: it has an index (a good one), but it has no bibliography, although this is only a minor problem. And the introduction has quotes and references that don't actually tell the reader the source.

Regardless, it is an excellent book for anyone interested in the idea of regional folklore and especially so for those who happen to dabble in that sort of journalism. Perhaps we all do from time to time. It is filled with good, descriptive folklore, removed only from the abstracted world of our variable theories, made concrete through the thoughts and pens of writers whose job can simply be to describe well. These are fresh looks at Texan folklore, of the sort we rarely have the chance to take on our trips through scholarly journals.

Philip Hiscock Memorial University St. John's, Newfoundland

Men at Play: A Working Understanding of Professional Hockey. By Michael A. Robidoux. (Montreal and Kingston: McGill-Queen's University Press, 2001, 222.p. ISBN 0-7735-2169-0 cloth; ISBN 0-7735-22204 pbk).

As a folklorist working in a kinesiology department, Michael Robidoux is a rarity who represents the truly interdisciplinary nature of folkloristics. Men at Play, based on his dissertation research at Memorial University of Newfoundland, is an ethnography of professional hockey that gives a serious attempt at understanding professional sport through the vision of its players - a folkloric approach to questions more typically reserved for sociologists and cultural theorists. As a former hockey player himself, Robidoux was able to follow a team of the American Hockey League (AHL) for one year and document and analyze the lives of its players. By focusing on these players and their interpretations, he debunks many of the myths of professional sport that are commonly presented in popular media and academic discourse. 
Robidoux's introductory notes on ethnography and the insider/ outsider dilemma make this text valuable as an instructional tool for learning how to begin fieldwork. While he includes a great deal of information on his relationship to the subject and to the players, he successfully uses this to situate his research and analysis. It is this personal connection that allows Robidoux to gain such a high level of access and to better interpret the material from the perception of the athletes. For example, he scrutinizes the complex problem of blanket accusations against hockey as violent, sexist, and homophobic. He demonstrates that these outward perceptions are not entirely held by its members and that, despite popular assumptions, professional sport is not an easy route to financial and social success for the vast majority of its players.

In Chapter One, Robidoux draws on Marxist theory to examine the production of self in professional hockey. The goal here is to show how self-identity is related to occupation (production) and thus why the occupation of professional hockey becomes the primary identifying element of its members. He uses Marx to discuss the decreasing levels of individuality created by increasing control of labour forces in capitalist economies. Robidoux's argument, however, is that despite this continuously increasing loss of control, individual players continue to find increasingly innovative ways to stamp their individuality onto their occupations, i.e., although professional hockey may be a highly regulated occupation where players are given little control over their lives, it is an arena of creative individuals who resist the hegemonic forces of the manufactured structure. Thus, through resistant forms of creation, there emerges an underlying artistic nature to hockey that works outside the controls of the capitalistic system.

With the aid of Roland Barthes and Michael Foucault, Robidoux continues on to show us the hegemonic nature of professional hockey that leads players to an inaccurate understanding of individual power and control. It is this power imbalance that glorifies the physical nature of the body, that turns the body into a commodity, and that produces men who oftentimes lack the necessary skills to live independently once they leave the realm of hockey. Robidoux's point is that the commodification of the young body devalues the importance of education and, despite popular notions of fame and fortune, leaves many young men stranded and bankrupt by the time they are thirty. Essentially, the body satisfies the industry yet corrodes the soul. He concludes: 
In the case of professional hockey, it is apparent that the heroic values placed upon players are largely superficial, and that the hockey player's ability to physically dominate an opponent has little currency outside the sporting arena. In fact, it is the hockey player's dependence on his body that denies him access to the very system of power that dictates his professional career, and to a certain extent his life (28).

In order to properly interpret the role of hockey in Canadian society, Robidoux devotes Chapter Two to the history and development of hockey and sport in Canada. The initial question posed here is: "How does a game known primarily for its violence and speed represent a nation known internationally as a moderator of violence and disputes and, moreover, as unreasonably polite" (32)? While the disjuncture of violent sport and peaceful nation is not fully explained, the role of hockey as a national symbol is thoroughly defined. Robidoux begins with a study of how the ruling class in England used sport to control the leisure time of the working class and how Canadians rejected much of this British and class-based identity through the rejection of British sports such as cricket. Similarly, lacrosse, a sport partly developed by Canada's First Nations Peoples, was rejected as a national sport because of its emerging class-based affiliations. While Robidoux argues that the origins of hockey are ambiguous, he clearly shows how this is a uniquely Canadian sport which is embraced by all levels of society.

Robidoux demonstrates that the history and ideology of hockey as a national sport help maintain a high level of popularity and a level of mistreatment of its players. This is a big money sport, but few of these players ever achieve financial security because it is difficult for them to push for better treatment when they must be seen as playing for the country as Canadian heroes _ " "...although hockey is undoubtedly Canadian, the game of professional hockey is undoubtedly corporate" (49). The corporate and occupational aspects of the sport are best demonstrated by his descriptions of the arena and the rigid complex practice drills that he observed (Chapter 3).

For the remainder of this text, there is a greater emphasis on the interpretation of hockey by the hockey players themselves. For example, while violence is often seen as spectacle by the audience, Robidoux presents it as serious and real for the players - an often time unavoidable aspect of the sport which has a serious physical and occupational impact on the players. An interpretation of the audience's perception of the game brings Robidoux into a discussion of Mikhail Bakhtine's 
"carnivalesque." An interpretation by the players themselves, however, is primarily in terms of labour and production. He uses play theory mainly that of John Huizinga and Roger Caillois — to show that for professional hockey "players," hockey is not simply a form of "play."

After a detailed description of rituals that he observed with the AHL team, Robidoux brings in theories from Arnold van Gennep and Victor Turner. With the aid of Jacques Derrida, however, he debunks the notion of liminality in these rituals for they assume a center that is not necessarily held by the hockey players. What is overlooked, according to Robidoux, is that the center for the hockey player is not the same as the center for the outsider. Therefore, outsiders who interpret initiation rituals with a focus on nudity and homoeroticism fail to understand the rituals from the participant's perspective. Being naked with a group of men, for a man who spends part of every day naked in a locker room with these men, has a very different meaning for the participant then it does for members of the outside world. As a result, rituals involving group nudity do not necessarily strip the participants of their identities and form a liminal state, an idea that goes contrary to most interpretations of rites of passage. Robidoux discovered through his fieldwork that hockey rituals do increase group unity and separation from the nonhockey world, but that this construction of unity works very differently than that assumed by many scholars. His discussion of ritual focuses on a number of issues of anxiety in initiations and locker room antics, thus revealing the complex nature of liminality and center, and the difficulty of interpretation by outside sources.

While focusing on the issue of power in hockey life (Chapter 7), Robidoux shows that the construction of masculinity is one of the strongest forms of socialization in professional hockey. This is demonstrated primarily through language - with an analysis of the underlying and unconscious meanings and functions of verbal and physical communication on the ice. This analysis then brings us to a discussion of the play of power, hypermasculinity, and intimacy. While the language is openly homophobic, the hypermasculine nature of the occupation allows interactions that could be deemed homoerotic to outside viewers, but which in reality reflect a firm security of identity of the players.

The existence and importance of "play" is revisited in the final chapter when Robidoux explores the issue of power and individuals. 
Hockey players create play outside the corporate game and thus reassert their own interests into their livelihood in a counter-hegemonic fashion. This is a necessary aspect of power and a reason players maintain dedication to the game despite what has been shown as a generally harsh atmosphere. Robidoux reminds us, "Hegemony consists of a giveand-take relationship between the dominant and the dominated classes; thus it is inevitable that those in power will occasionally concede minimal victories in order to secure their own dominant position" (176).

While the topic of professional hockey falls outside the realm of many folklorists, Robidoux's work shows the value of a folkloristic approach to non-traditional matters. In addition to providing an indepth understanding of this sport/occupation, it contributes to theories of ritual, masculinity, play, and power. Furthermore, we are introduced to the issues of the commodified body in the capitalist structure and the ability of industry/game to subdue the worker/player. Robidoux concludes that it is time to recognize and treat hockey for what it is an occupation. Without this recognition, players will never be able to overcome the "professional hockey hegemony" that dominates the Canadian industry.

Corey Thorne University of Pennsylvania Philadelphia, PA

Blood, Sweat, and Cheers: Sport and the Making of Modern Canada. By Colin Howell. (University of Toronto Press, 2001, viii + 161 p., selected bibliography, index, ISBN 0-8020-8248-3)

The temptation in reviewing Blood, Sweat, and Cheers is to assess it for what it is not, that is Bruce Kidd's The Struggle for Canadian Sport (1996). Kidd's work is still the defining work on the development and state of sport in Canada, and Blood, Sweat, and Cheers does little to advance any further knowledge in this area of study. With this said, Howell provides an exceptionally well written, concise and well organized account of sport development in Canada which would serve as an excellent introductory text for classes in Canadian sport history.

Howell begins by listing the dominant trends in terms of sport history scholarship which he incorporates at various points in the book to speak to the "contested social meanings and values" (7) of Canadian sport. His intention is not only to discuss the developments of sport in Canada, 